\title{
Association of clinical, social and environmental variables with dental caries prevalence in adolescents from a Brazilian municipality supplied with fluoridated water
}

\author{
Associação de variáveis clínicas, sociais e ambientais sobre a cárie \\ dentária em adolescentes de um município brasileiro com água \\ fluoretada
}

\author{
Ana Paula Ferreira Marques ${ }^{1}$ (D), Aretuza Pires dos Santos Lattanzi ${ }^{1}$ (D), Flavia Maia Silveira² (D), \\ Maria Isabel Bastos Valente ${ }^{2}$ (D), Karine Laura Cortellazzi ${ }^{3}$ (D) Andréa Videira Assaf ${ }^{2}$ (D) \\ 'Postgraduate Program in Dentistry, Universidade Federal Fluminense (UFF) - Nova Friburgo (RJ), Brasil. \\ ${ }^{2}$ Department of Specific Formation, School of Dentistry, Universidade Federal Fluminense (UFF) - Nova Friburgo (RJ), Brasil. \\ ${ }^{3}$ Department of Public Health, School of Dentistry, Universidade Estadual de Campinas (UNICAMP) - Piracicaba (SP), Brasil.
}

How to cite: Marques APF, Lattanzi APS, Silveira FM, Valente MIB, Cortellazzi KL, Assaf AV. Association of clinical, social and environmental variables with dental caries prevalence in adolescents from a Brazilian municipality supplied with fluoridated water. Cad Saúde Colet, 2021;29(4):551-560. https://doi.org/10.1590/1414-462X202129040345

\begin{abstract}
Background: Although a trend towards dental caries reduction has been observed, further investigations on its pattern and development are still needed. Objective: To investigate the influence of clinical, social and environmental variables on dental caries prevalence in adolescents from a Brazilian municipality supplied with fluoridated water in 2018. Method: This study was conducted with a non-probabilistic sample of 277 adolescents aged 12 years of public schools in Nova Friburgo, state of Rio de Janeiro, Brazil. Clinical examinations were carried out by calibrated examiners to assess caries, periodontal disease, and fluorosis according to criteria of the World Health Organization (WHO). Semi-structured questionnaires were applied to record socio-environmental information. Results: Individuals living in regions supplied with fluoridated water below the minimum required levels $(\mathrm{O}=3.60, p=0.0006)$, with low income $(\mathrm{OR}=1.90, p=0.0444)$, presence of gingivitis $(\mathrm{OR}=3.36 ; p=0.0016)$, and whose reason for visiting the dentist was dental treatment $(\mathrm{OR}=2.41 ; p=0.0203)$ were more likely to have dental caries. A significant reduction $(p<0.0001)$ in dental caries indexes was observed between 2012 and 2018. Conclusion: Fluoridation of public water supply at unsuitable levels, as well as other social and clinical variables can influence the caries pattern in adolescents.
\end{abstract}

Keywords: fluoridation; epidemiological studies; dental caries.

\section{Resumo}

Introdução: A tendência de redução da cárie dentária tem sido constatada, apesar de maiores investigações sobre seu padrão e desenvolvimento serem ainda necessárias. Objetivo: investigar a influência de variáveis clínicas, sociais e ambientais sobre a cárie em adolescentes de um município brasileiro com água fluoretada, no ano de 2018. Método: Empregou-se uma amostra não probabilística de 277 adolescentes de 12 anos, de escolas públicas de Nova Friburgo, Rio de Janeiro, Brasil. Exames clínicos foram realizados por examinadores calibrados, para avaliação de cárie, doença periodontal e fluorose, sob critérios da Organização Mundial da Saúde (OMS). Questionários semiestruturados foram aplicados para coletar informações socioambientais. Resultados: Indivíduos

This is an Open Access article distributed under the terms of the Creative Commons Attribution License, which permits unrestricted use, distribution, and reproduction in any medium, provided the original work is properly cited. 
residentes em regiões com flúor na água em subdoses ( $O R=3,60, p=0,0006)$, e aqueles com baixa renda ( $O R=1,90, p=0,0444)$, com presença de gengivite $(O R=3,36 ; p=0,0016)$ e cuja razão para a visita ao dentista foi para tratamento dentário $(\mathrm{OR}=2,41 ; 0,0203)$, apresentaram mais chances de terem cárie. Uma redução significativa $(p<0,0001)$ nos índices de cárie foi observada entre 2012 (primeiro levantamento epidemiológico) e 2018. Conclusão: A fluoretação das águas de abastecimento público, quando em níveis não adequados, assim como outras variáveis sociais e clínicas, podem influenciar o padrão de cárie nos adolescentes.

Palavras-chave: fluoretação; estudos epidemiológicos; cárie dentária.

\section{INTRODUCTION}

Recently published scientific investigations show that there is general acceptance that tooth decay has been considerably modified over the past two decades, especially in the young groups, mainly due to access to fluoride toothpastes and fluoridation of public water supplies ${ }^{1-3}$.

However, dental caries is still considered an important public health problem in both-industrialized and developing countries ${ }^{4-6}$. There are now a considerable number of scientific studies, ranging from the simple description of the problem in different age groups and localities to those showing that knowledge about the relations of social determinants is an important tool for understanding this condition ${ }^{2-4,6-8}$.

The evaluation of socioeconomic determinants has frequently been addressed in oral health studies conducted with adolescents, especially dental caries, since it allows a description of the situation of this population in relation to their living conditions, making it possible to establish a direct relationship with the prevalence of this condition ${ }^{6-9}$. Among the variables analyzed for socioeconomic classification of individuals, family income has been considered of adequate discriminatory power, since children belonging to families with different income levels show significant differences in dental caries indicators ${ }^{6,10}$.

The influence of intermediate social determinants, such as those related to environmental conditions, e.g., domiciles/peridomiciles, workplaces, and factors that lead to inequalities in the access to services and oral health promotion programs and preventive measures, such as fluoridation of public water supplies, could also be ways to explain the contemporary picture of oral health inequalities in different localities and age groups. For instance, epidemiological studies have shown that fluoridated water supply and oral health promotion programs in schools have been considered resources to protect children and adolescents from the development of caries ${ }^{11-13}$.

Thus, this study aimed to investigate the influence of clinical, social and environmental variables on dental caries prevalence in adolescents from a Brazilian municipality supplied with fluoridated water in 2018.

\section{METHOD}

\section{General and ethical aspects}

This study, developed in 2018, was approved by the Research Ethics Committee (REC) of the Health Institute of Nova Friburgo under protocol no. 2.402.679 - CAAE: 76415817.2.0000.5626. The participating adolescents and their legal guardians signed an Informed Consent Form (ICF) prior to study commencement. It is relevant to point out that some information of oral health was also obtained from a previous study ${ }^{9}$, implemented in 2012, approved by the REC of the Federal Fluminense University, Antonio Pedro Hospital (HUAP), under protocol no. 272/2010 - CAAE: 0217.0.258.000-10.

This cross-sectional study was carried out in accordance with the Strengthening the Reporting of Observational Studies in Epidemiology (STROBE) guidelines. This study (second oral health survey) used the same methodology of Assaf et al. ${ }^{9}$ (first oral health survey). 


\section{Sample}

The non-probabilistic sample was composed of 12-year-old adolescents regularly enrolled in public schools in the municipality of Nova Friburgo in 2018. For sample calculation, the clinical outcome dental caries was considered in $60 \%$ of 12 -year-old schoolchildren in the municipality, obtained from the 2012 survey ${ }^{9}$, with $5 \%$ precision and $95 \%$ confidence interval, resulting 270 individuals. The participants were selected from lists of schoolchildren enrolled in all public schools of the municipality. Adolescents whose legal guardians did not sign the ICF and who presented some systemic impairment were excluded from the study.

\section{Study phases}

This study was conducted in two phases: a) Preparatory phase: calibration of examiners and pilot study; b) Data collection: application of semi-structured questionnaires for sociodemographic evaluation and access to dental services, evaluation of the presence of fluoride in the water of the different regions of the municipality, assessment of the presence of preventive activities with impact on oral health in schools, and clinical examination of the participants regarding dental caries, dental fluorosis, and periodontal condition.

\section{Preparatory phase}

\section{Calibration of examiners and pilot study}

Calibration of the examiners $(n=2)$, which lasted $20 \mathrm{~h}$, was conducted by a researcher with previous experience in epidemiological surveys, and presented an interrater kappa value of 0.87 .

The pilot study was carried out with 10 adolescents and their legal guardians, prior to the beginning of the data collection phase, to ensure that the participants understood the questionnaire and train the researchers to conduct both the interviews and epidemiological examinations.

\section{Data collection}

\section{Application of questionnaires}

The semi-structured questionnaire about socioeconomic conditions and access to dental services was based on the instrument proposed by Brazil ${ }^{14}$, and was responded by the adolescents' legal guardians.

\section{Evaluation of the presence of fluoride in the water supply of different locations in the municipality}

This variable was evaluated based on the standard of fluoride content in the samples collected monthly in different geographic locations, as a measure of health surveillance performed in the municipality in partnership with a public university since $2011^{15}$. Through the mapping of the municipal water fluoridation system applied during the seven years of monthly sample analysis, a classification criterion was established for each municipal district based on the parameters previously established at the Federal level. According to the parameters of the Ministry of Health Collaborating Center for Oral Health Surveillance (CECOL), municipalities with mean annual temperature $<26^{\circ} \mathrm{CF}$ should ideally have fluoride concentration in the $0.65-0.94$ ppmF range. This is because these parameters represent the maximum benefits to prevent caries, with lower risk for the occurrence of fluorosis.

Evaluation of the presence of educational-preventive activities, with impact on oral health, at the schools attended by the adolescents participating in the study

Oral health professionals in the municipality developed educational-preventive actions in oral health for groups of schoolchildren, with a semiannual periodicity, in some school spaces. These mainly involved the mechanical control of dental biofilm, with supervised tooth brushing, 
in addition to providing the adolescents with guidelines for adopting a balanced healthy diet. Thus, the presence of educational-preventive activities in oral health at schools - evaluated for at least two years - was also considered as a variable of analysis.

\section{Clinical examinations}

The clinical examinations, conducted according to the methodology recommended by the World Health Organization (WHO) ${ }^{16}$, were performed by calibrated examiners in an outdoor setting, under natural light, with the use of a plane oral mirror and a periodontal probe (WHO 621). To facilitate visual diagnosis, supervised tooth brushing was performed before the examination to remove possible biofilm and food debris from the dental surfaces.

The following indexes were used to evaluate dental caries: Decayed, Missing, and Filled Teeth (DMFt) (mean number of decayed, missing and filled permanent teeth) and Significant Caries Index ( $\mathrm{SiC}$ ). Presence of gingivitis and dental calculus was verified, and dental fluorosis was verified using the Dean's Fluorosis Index ${ }^{5,16}$.

\section{Data analysis}

Initially, analyses were performed on some variables common to the databases of the two studies (2012 and 2018) to characterize the social profile and clinical outcomes in oral health (Tables 1 and 2). Normal distribution of both samples was not confirmed by the Kolmogorov-Smirnov test. Thus, inferential analyses were performed using the Mann Whitney test to compare the means relative to the clinical conditions of the participants from the two surveys and Chi-squares tests to compare the proportions (Table 2)

For the 2018 data analysis, crude and adjusted analyses were performed to test the association between the dependent variable, dental caries, dichotomized by the median (DMFt $\leq 0$ and DMFt $>0$ ), and the dichotomized independent sociodemographic and clinical variables investigated according to Assaf et al. ${ }^{9}$. The variables that presented $p<0.20$ in the crude analysis were tested by multiple logistic regression, with $p \leq 0.05$ as a criterion for the variable to remain in the final model. Statistical tests were performed using the SAS 9.4 statistical software (SAS Institute Inc., NC, USA).

\section{RESULTS}

The final sample of the 2018 study was composed of 277 adolescents, $15.52 \%$ from the rural area and $84.48 \%$ from the urban area. Of the individuals examined, $59.93 \%$ were females and $40.07 \%$ males. When the distributions of the independent variables of the two surveys carried out in the municipality (2012 and 2018) were compared, a pattern of percentage similarity was found for most of them (Table 1).

Evaluation of oral health related to both surveys showed significant reductions in caries, with respect to the DMFt index $(p<0.0001)$ and its components, decayed $(p<0.0001)$ and filled $(p<0.0023)$ teeth, as well as to the $\mathrm{SiC}$ index $(p<0.0001)$. On average, there was reduction of one unit in the DMFt index and of two units in the $\mathrm{SiC}$ index. There was an increase of approximately $40 \%(p=0.0000)$ in caries-free individuals, and of almost $20 \%$ in those with fluorosis $(p=0.0000)$ (Table 2).

In the multiple regression analysis, adjusted analysis showed that individuals living in the locations supplied with fluoridated water below the minimum required levels were more likely to present caries $(\mathrm{OR}=3.60 ; p=0.0006)$ compared with those going to school in locations supplied with fluoridated water at adequate levels. In addition, individuals with gingivitis and with lower income were, respectively, $3.36(\mathrm{OR}=3.36, p=0.0016)$ and 1.9(OR=1.90, $p=0.0444)$ times more likely to have dental caries. Reason for visiting the dentist due to dental treatment was also significantly associated with the presence of caries ( $O R=2.41, p=0.0203)$ (Table 3). 
Table 1. Sociodemographic characteristics and data on access to dental services of the participants with reference to the two oral health surveys conducted in the municipality of Nova Friburgo. Nova Friburgo, RJ, Brazil, 2019

\begin{tabular}{|c|c|c|c|c|}
\hline \multirow{2}{*}{ Variables/Year } & \multicolumn{2}{|c|}{2012} & \multicolumn{2}{|c|}{2018} \\
\hline & $\mathbf{n}$ & $\%$ & $\mathbf{n}$ & $\%$ \\
\hline \multicolumn{5}{|l|}{ School location area } \\
\hline Rural & 236 & 46.83 & 43 & 15.52 \\
\hline Urban & 268 & 53.17 & 234 & 84.48 \\
\hline \multicolumn{5}{|l|}{ Sex } \\
\hline Female & 276 & 54.76 & 166 & 59.93 \\
\hline Male & 228 & 45.24 & 111 & 40.07 \\
\hline \multicolumn{5}{|l|}{ Parental education level } \\
\hline$\leq 8$ years & 285 & 61.29 & 152 & 67.26 \\
\hline$>8$ years & 180 & 38.71 & 74 & 32.74 \\
\hline \multicolumn{5}{|l|}{ Family income BMW* } \\
\hline$\leq$ median & 381 & 78.07 & 104 & 50.00 \\
\hline >median & 107 & 21.93 & 104 & 50.00 \\
\hline \multicolumn{5}{|l|}{ Household agglomeration } \\
\hline$\leq 1.67$ & 244 & 50.21 & 136 & 58.87 \\
\hline$>1.67$ & 242 & 49.79 & 95 & 41.13 \\
\hline \multicolumn{5}{|l|}{ Visit to the dentist } \\
\hline Yes & 416 & 84.21 & 228 & 86.04 \\
\hline No & 78 & 15.79 & 37 & 13.96 \\
\hline \multicolumn{5}{|l|}{ Reason for the visit } \\
\hline Routine & 114 & 27.08 & 84 & 35.00 \\
\hline Treatment (pain, extraction, filling) & 307 & 72.92 & 156 & 65.00 \\
\hline
\end{tabular}

*Median, in 2018, corresponded to 1.16 Brazilian minimum wage (BMW) and median, in 2012, corresponded to 3 BMWs

Table 2. Caries and fluorosis pattern of the participants with reference to the two oral health surveys conducted in the municipality of Nova Friburgo. Nova Friburgo, RJ, Brazil, 2019

\begin{tabular}{lccc}
\hline \multicolumn{1}{c}{ Oral conditions } & $\begin{array}{c}\mathbf{2 0 1 2} \\
\mathbf{n = 5 0 4}\end{array}$ & $\begin{array}{c}\mathbf{2 0 1 8} \\
\mathbf{n = 2 7 7}\end{array}$ & $\boldsymbol{p}$-value \\
\hline Caries-free individuals $\mathbf{n}(\%)$ & $201(39.88)$ & $167(60.29)$ & $p=0.0000^{* *}$ \\
\hline DMFt (SD) & $1.90(2.25)$ & $0.85(1.51)$ & $p<0.0001^{*}$ \\
\hline $\mathbf{D}$ (SD) & $0.98(1.67)$ & $0.48(1.14)$ & $p<0.0001^{*}$ \\
\hline M (SD) & $0.08(0.42)$ & $0.01(0.15)$ & $p=0.4885^{*}$ \\
\hline F (SD) & $0.84(1.46)$ & $0.40(0.95)$ & $p<0.0023^{*}$ \\
\hline DMFt rural area (SD) & $1.98(2.29)$ & $1.09(1.25)$ & $p<0.0035^{*}$ \\
\hline DMFt urban area (SD) & $1.82(2.17)$ & $0.85(1.59)$ & $p<0.0001^{*}$ \\
\hline SiC (SD) & $4.54(1.90)$ & $2.47(1.82)$ & $p<0.0001^{*}$ \\
\hline Individuals with fluorosis $\mathbf{n}$ (\%) & $35(7.64)$ & $73(26.35)$ & $p=0.0000^{* *}$ \\
\hline
\end{tabular}

Mann Whitney test*; Chi squared test**; SD: standard deviation 
Table 3. Crude and adjusted analyses of caries presence (DMFt $>0$ ) as a function of the independent

\begin{tabular}{|c|c|c|c|c|c|c|c|c|}
\hline & \multicolumn{2}{|c|}{ DMFt } & \multicolumn{3}{|c|}{ Crude analysis } & \multicolumn{3}{|c|}{ Adjusted analysis } \\
\hline & $\leq 0 \mathrm{n}(\%)$ & $>0 \mathrm{n}(\%)$ & Crude OR & $\mathrm{Cl} 95 \%$ & $p$ value & $\begin{array}{l}\text { Adjusted } \\
\text { OR }\end{array}$ & Cl95\% & p value \\
\hline \multicolumn{9}{|l|}{ Fluoride levels in water } \\
\hline Fluoridated below level & $26(39.39)$ & $40(60.61)$ & 3.03 & $1.71-5.38$ & 0.0001 & 3.58 & $1.73-7.40$ & 0.0006 \\
\hline Fluoridated to ideal level & $\begin{array}{c}136 \\
(66.34)\end{array}$ & $69(33.66)$ & ref & & & ref & & \\
\hline Fluoridated above level & $3(5.00)$ & $3(50.00)$ & 1.97 & $0.39-10.02$ & 0.4135 & 3.41 & $0.5-23.34$ & 0.2107 \\
\hline \multicolumn{9}{|l|}{ Individual variables } \\
\hline \multicolumn{9}{|l|}{ School area } \\
\hline Rural & $18(41.86)$ & $25(58.14)$ & 2.35 & $1.21-4.55$ & 0.0115 & & & \\
\hline Urban & $\begin{array}{c}147 \\
(62.82)\end{array}$ & $87(37.18)$ & ref & & & & & \\
\hline \multicolumn{9}{|c|}{ Educational-preventive activities } \\
\hline Absence & $\begin{array}{c}131 \\
(61.21)\end{array}$ & $83(38.79)$ & ref & & & & & \\
\hline Presence & $34(53.97)$ & $29(46.03)$ & 1.35 & $0.76-2.37$ & 0.3038 & & & \\
\hline \multicolumn{9}{|l|}{ Sex } \\
\hline Female & $97(58.43)$ & $69(41.57)$ & 1.13 & $0.69-1.84$ & 0.6385 & & & \\
\hline Male & $68(61.26)$ & $43(38.74)$ & ref & & & & & \\
\hline \multicolumn{9}{|l|}{ Gingivitis } \\
\hline Absence & $\begin{array}{c}132 \\
(62.86)\end{array}$ & $78(37.14)$ & ref & & & ref & & \\
\hline Presence & $27(47.37)$ & $30(52.63)$ & 1.88 & $1.04-3.39$ & 0.0361 & 3.36 & $1.58-7.12$ & 0.0016 \\
\hline \multicolumn{9}{|l|}{ Dental pain } \\
\hline No & $80(60.15)$ & $53(39.85)$ & ref & & & & & \\
\hline Yes & $85(59.03)$ & $59(40.97)$ & 1.05 & $0.65-1.69$ & 0.8492 & & & \\
\hline \multicolumn{9}{|l|}{ Fluorosis } \\
\hline No & $\begin{array}{c}126 \\
(62.07)\end{array}$ & $77(37.93)$ & ref & & & & & \\
\hline Yes & $39(53.42)$ & $34(46.58)$ & 1.43 & $0.83-2.45$ & 0.1974 & & & \\
\hline \multicolumn{9}{|l|}{ Parental schooling } \\
\hline$\leq 8$ years & $92(60.53)$ & $60(39.47)$ & 1.07 & $0.61-1.90$ & 0.8134 & & & \\
\hline$>8$ years & $46(62.16)$ & $28(37.84)$ & ref & & & & & \\
\hline \multicolumn{9}{|l|}{ Family income $(B M W)^{*}$} \\
\hline$\leq 1.16$ & $55(52.88)$ & $49(47.12)$ & 1.89 & $1.07-3.33$ & 0.0273 & 1.90 & $1.02-3.55$ & 0.0444 \\
\hline$>1.16$ & $70(67.96)$ & $33(32.04)$ & ref & & & ref & & \\
\hline \multicolumn{9}{|l|}{ Household agglomeration } \\
\hline$\leq 1.7$ & $75(64.10)$ & $42(35.90)$ & ref & & & & & \\
\hline$>1.7$ & $67(58.77)$ & $47(41.23)$ & 1.25 & $0.74-2.13$ & 0.4055 & & & \\
\hline
\end{tabular}

*Median corresponded to 1.16 Brazilian minimum wage (BMW) in 2018; ref: reference; OR: Odds Ratio; Cl: Confidence Interval; DMFT $>0$ is the reference for dependent variable 
Table 3. Continued...

\begin{tabular}{|c|c|c|c|c|c|c|c|c|}
\hline & \multicolumn{2}{|c|}{ DMFt } & \multicolumn{3}{|c|}{ Crude analysis } & \multicolumn{3}{|c|}{ Adjusted analysis } \\
\hline & $\leq 0 \mathrm{n}(\%)$ & $>0$ n (\%) & Crude OR & $\mathrm{Cl} 95 \%$ & p value & $\begin{array}{c}\text { Adjusted } \\
\text { OR }\end{array}$ & $\mathrm{Cl} 95 \%$ & p value \\
\hline \multicolumn{9}{|l|}{ Visit to the dentist } \\
\hline Yes & $38(60.53)$ & $90(39.47)$ & ref & & & & & \\
\hline No & $21(56.76)$ & $16(43.24)$ & 1.17 & $0.58-2.36$ & 0.6644 & & & \\
\hline \multicolumn{9}{|l|}{ Last visit to the dentist } \\
\hline$<1$ year & $66(61.68)$ & $41(38.32)$ & ref & & & & & \\
\hline$\geq 1$ year & $78(58.65)$ & $55(41.35)$ & 1.14 & $0.67-1.91$ & 0.6333 & & & \\
\hline Never went to the dentist & $21(56.76)$ & $16(43.24)$ & 1.23 & $0.58-2.62$ & 0.6333 & & & \\
\hline \multicolumn{9}{|l|}{ Reason for the visit } \\
\hline Routine & $61(72.62)$ & $23(27.38)$ & ref & & & ref & & \\
\hline Treatment & $83(53.21)$ & 73 (46.79) & 2.33 & $1.32-4.14$ & 0.0038 & 2.41 & $1.15-5.05$ & 0.0203 \\
\hline Never went to the dentist & $22(56.76)$ & $16(43.24)$ & 2.02 & $0.90-4.53$ & 0.0880 & 1.74 & $0,62-4,89$ & 0.2972 \\
\hline \multicolumn{9}{|l|}{ Type of service } \\
\hline Public & $57(58.76)$ & $40(41.24)$ & 1.08 & $0.64-1.82$ & 0.7804 & & & \\
\hline Private & $86(60.56)$ & $56(39.44)$ & ref & & & & & \\
\hline Never went to the dentist & $22(57.89)$ & $16(42.11)$ & 1.12 & $0.54-2.31$ & 0.7656 & & & \\
\hline
\end{tabular}

*Median corresponded to 1.16 Brazilian minimum wage (BMW) in 2018; ref: reference; OR: Odds Ratio; Cl: Confidence Interval; DMFT $>0$ is the reference for dependent variable

\section{DISCUSSION}

This study showed an improvement in the dental caries pattern, due to significant reductions in the DMFt and $\mathrm{SiC}$ indexes, and an increase in the number of caries-free individuals, six years after the first epidemiological survey carried out in the municipality (Table 2$)^{9}$. The DMFt value of the 2018 study (0.85) was smaller than the national level and that of the Southeast region of the country, according to information obtained in the last national survey carried out in $2011^{14}$. Moreover, this value attained the goal for 2020 proposed by the WHO - DMFT $<1.5$ at 12 years of age $^{17}$. The percentage of caries-free individuals also increased from $39.88 \%$ in 2012 to $60.29 \%$ in 2018, which shows that the 12-year-old adolescents of Nova Friburgo have a better oral health condition compared with those in the state of Rio de Janeiro (50.60\%) and with Brazilian adolescents as a whole $(43.50 \%)^{9,14}$. However, despite the significant reduction in the SiC index evaluated between 2012 and 2018, caries was still clearly polarized in the group of adolescents, with the SiC index showing a value nearly 3 times higher than that of the DMFt index.

Access to dental treatment and improvement in oral health conditions may not be necessarily directly related ${ }^{18}$. The results of the present study showed significant association between going to the dentist to perform treatment and presence of dental caries (Table 3 ). These results corroborated the findings of Nadanovsky et al. ${ }^{18}$, who demonstrated that dental services in 18 countries had little influence on the change in the caries profile between the 1970s and 1980s. However, as pointed out by Celeste et al. ${ }^{19}$, services focused on preventive activities can have a beneficial effect on reducing tooth decay. Therefore, these findings could possibly be justified by professional performance within a surgical-restorative philosophy that has maintained a care model that, although outdated, is still perpetuated in oral health practices. 
The association between caries and gingivitis is well-known, and has been reported in the literature ${ }^{4}$. These oral conditions have presence of biofilm on dental surfaces in common, as an etiological factor ${ }^{20}$. In this study, presence of gingivitis was related to a greater chance of developing caries compared with the absence of this condition, which further reinforces the need to invest in oral health promotion by making adolescents aware of the importance of self-care (Table 3).

There is evidence that the main reasons for health inequalities are social, economic and political. Family income is a socioeconomic determinant strongly associated with oral health. The impact of income on oral health can be understood, as it affects greater access to information, services, and especially education, among other factors, since it directly influences the conception of health-related behaviors. In the multiple logistic regression model, the income variable was significantly associated with presence of caries, and this result agrees with those of studies that related inequalities in oral health to socioeconomic conditions $s^{6-9}$.

Fluoridation of public water supply has been recognized as an effective caries prevention measure ${ }^{2,3}$. Studies have demonstrated the preventive effects of this measure and shown that the number of teeth affected by caries was lower in communities that have access to fluoridated water compared with those that do not have this beneficial measure ${ }^{2,3,11,12}$. It is important to note that, even in countries that have abandoned this preventive measure, such as Canada and Australia, studies defend its maintenance. An example is observed in McLaren et al. ${ }^{3}$, who assessed the short-term impact of fluoridation cessation in Canadian children and observed an increase in dental caries in primary teeth. Another recent study carried out with indigenous Australian children shows that, although the annual reduction in caries is more significant with the introduction of preventive programs using individual fluoride methods, they present higher cost, greater logistic, and difficult feasibility to be maintained over time compared with water fluoridation, and advocate fluoridation as a permanent public health preventive measure ${ }^{21}$. Additionally, a study reported that, even in situations of social deprivation, children with access to fluoridated water had better oral health than those who did not have access to it ${ }^{2}$.

It should be emphasized that fluoridation of public water supply is only effective in preventing caries if implemented constantly and at adequate fluoride concentration ${ }^{15}$. This study suggested an association of fluoridated water and DMFt, pointing out that adolescents attending schools supplied with fluoridated water below the minimum required level were 3.6 times more likely to have dental caries than those attending schools supplied with fluoridated water at appropriate levels. Therefore, not only is the effectiveness of the fluoridation measure important in caries prevention, but so is the need for its maintenance over time, based on an adequate system of monitoring fluoride at adequate concentrations that will benefit the population in the form of protection $3,12,15$.

It is worth mentioning that the first epidemiological survey, carried out in 2012, coincides with the beginning of the introduction of this preventive measure in the municipality. However, although a reduction in caries prevalence has been observed over time, the effect of this measure on this improvement cannot be proved. For this, it would be necessary to conduct a multiple model with sectional data from different years, e.g., 2012-2018, with control of other confounding variables, or even with follow-up studies of the same population group.

Although this study reached the required sample number, some limitations can be pointed out, specifically with the non-adherence of some adolescents to the survey. However, information obtained from the educational institutions showed that the individuals who did not participate in the study had socioeconomic and demographic characteristics similar to those of the participants. The impossibility to collect water in the residences of the participating adolescents to evaluate fluoride levels because of time and access issues also constitutes a study limitation. The solution found was to evaluate the fluoride concentration using a time series on the fluoridation scheme obtained from the municipality's health surveillance system. It is also relevant to mention that, in addition to evaluating water fluoridation and exposure of the adolescents to preventive programs, a thorough assessment of exposure to fluoride - based, for instance, on the daily use of toothpaste and other fluoride and methods of consumption of potentially fluoridated foods - has not been performed. In addition, the halo effect - in which 
the fluoridation of neighboring municipalities (e,g., Bom Jardim, Casimiro de Abreu, Trajano de Moraes, and Petrópolis) could affect the pattern of caries in the municipality of Nova Friburgo based on their production and/or commercialization of foods processed with fluoridated water, or even on urban intermunicipal mobility of people (not measured) - also constitutes a limiting factor of this study.

However, it should be emphasized that the control of the entire research process through a pilot study, calibration of the examiners, and control at the stage of data collection and analysis led to adequate internal validity of the study. Moreover, few studies have analyzed and correlated the presence, constancy and local pattern of fluoridation with the population dental caries pattern in the municipality over time ${ }^{12,22}$.

\section{ACKNOWLEDGEMENTS}

The authors are grateful to PROAP/CAPES for the financial support. We would also like to thank the Municipal and State Secretaries of Education, public school principals, parents, and all adolescents who participated in this study between 2012 and 2018.

\section{REFERENCES}

1. Ferreira RGLA, Marques RAA, Menezes LMB, Narvai PC. Múltiplos aspectos do uso do flúor em saúde pública na visão de lideranças da área de saúde. Cien Saude Colet. 2013 Jul;18(7):2139-46. http://dx.doi. org/10.1590/S1413-81232013000700029. PMid:23827918.

2. Kim HN, Kim JH, Kim SY, Kim JB. Associations of Community water fluoridation with caries prevalence and oral health inequality in children. Int J Environ Res Public Health. 2017;14(6):631. PMid:28608827.

3. McLaren L, Patterson S, Thawer S, Faris P, McNeil D, Potestio ML, et al. Exploring the short-term impact of community water fluoridation cessation on children's dental caries: a natural experiment in Alberta, Canada. Public Health. 2017;146:56-64. http://dx.doi.org/10.1016/j.puhe.2016.12.040. PMid:28404475.

4. World Health Organization. The World Oral Health Report 2003: continuous improvement of oral health in the 21st century: the approach of the WHO Global Oral Health Programme. Geneva: WHO; 2003.

5. Bratthall D. Introducing the significant caries index together with a proposal for a New Global Oral Health Goal for 12-year-olds. Int Dent J. 2000;50(6):378-84. http://dx.doi.org/10.1111/j.1875-595X.2000.tb00572.x. PMid:11197197.

6. Peres MA, Macpherson LMD, Weyant RJ, Daly B, Venturelli R, Mathur MR et al. Oral diseases: a global public health challenge. Lancet. 2019;394(10194):249-60. http://dx.doi.org/10.1016/S0140-6736(19)31146-8.

7. Sheiham A, Alexander D, Cohen L, Marinho V, Moysés S, Petersen PE, et al. Global oral health inequalities: task group--implementation and delivery of oral health strategies. Adv Dent Res. 2011 May;23(2):259-67. http://dx.doi.org/10.1177/0022034511402084. PMid:21490238.

8. Boing AF, Bastos JL, Peres KG, Antunes JL, Peres MA. Social determinants of health and dental caries in Brazil: a systematic review of the literature between 1999 and 2010. Rev Bras Epidemiol. 2014;17(Suppl 2):102-15. http://dx.doi.org/10.1590/1809-4503201400060009. PMid:25409641.

9. Assaf AV, Caldo-Teixeira AS, Silveira FM, Valente MIB, Ditterich RG, Barcelos R. Dental caries in inland Brazilian adolescents and its relationship with social determinants. Braz J Oral Sci. 2014;13(2):133-9. http://dx.doi. org/10.1590/1677-3225v13n2a11.

10. Cianetti S, Lombardo G, Lupatelli E, Rossi G, Abraha I, Pagano S, et al. Dental Caries, parents educational level, family income and dental service attendance among children in Italy. Eur J Paediatr Dent. 2017;18(1):15-8. PMid:28494596.

11. Antunes JLF, Narvai PC. Dental health policies in Brazil and their impact on health inequalities. Rev Saude Publica. 2010;44(2):360-5. http://dx.doi.org/10.1590/S0034-89102010000200018. PMid:20339637.

12. Cruz MGB, Narvai PC. Caries and fluoridated water in two Brazilian municipalities with low prevalence of the disease. Rev Saude Publica. 2018 Apr;52:28. http://dx.doi.org/10.11606/S1518-8787.2018052016330. PMid:29641653.

13. Aguiar VR, Pattussi MP, Celeste RK. The role of municipal public policies in oral health socioeconomic inequalities in Brazil: a multilevel study. Community Dent Oral Epidemiol. 2018;46(3):245-50. http://dx.doi. org/10.1111/cdoe.12356. PMid:29215153. 
14. Brasil. Ministério da Saúde. Secretaria de Atenção à Saúde. Departamento de Atenção Básica. Coordenação Nacional de Saúde Bucal. SB Brazil Project 2010: national oral health research: main results. Report. Brasília: Ministério da Saúde; 2011. 92 p.

15. Marques APF, Ferraz A, Lima Netto LG, Ditterich RG, Silveira FM, Caldo-Teixeira AS, et al. Access to fluoridated water: an overview since its implantation in a city of Rio de Janeiro State, Brazil. Rev Bras Odontol. 2018;75:e1124.

16. World Health Organization. Oral health surveys: basic methods. 5th ed. Geneva: WHO; 2013.

17. Hobdell M, Petersen PE, Clarkson J, Johnson N. Global goals for oral health 2020. Int Dent J. 2003;53(5):2858. http://dx.doi.org/10.1111/j.1875-595X.2003.tb00761.x. PMid:14560802.

18. Nadanovsky $P$, Sheiham A. Relative contribution of dental services to the changes in caries levels of 12-year-old children in 18 industrialized countries in the 1970s and early 1980s. Community Dent Oral Epidemiol. 1995;23(6):331-9. http://dx.doi.org/10.1111/j.1600-0528.1995.tb00258.x. PMid:8681514.

19. Celeste RK, Nadanovsky P, Leon AP. Associação entre procedimentos preventivos no serviço público de odontologia e a prevalência de cárie dentária. Rev Saude Publica. 2007;41(5):830-8. http://dx.doi. org/10.1590/S0034-89102007000500018. PMid:17923905.

20. Jepsen S, Blanco J, Buchalla W, Carvalho JC, Dietrich T, Dorfer C, et al. Prevention and control of dental caries and periodontal diseases at individual and population level: consensus report of group 3 of joint EFP/ORCA workshop on the boundaries between caries and periodontal diseases. J Clin Periodontol. 2017;44(18 Suppl 18):S85-93. http://dx.doi.org/10.1111/jcpe.12687. PMid:28266120.

21. Kroon J, Lalloo R, Tadakamadla SK, Johnson NW. Dental caries experience in children of a remote Australian Indigenous Community following passive and active preventive interventions. Community Dent Oral Epidemiol. 2019;47(6):470-6. http://dx.doi.org/10.1111/cdoe.12486. PMid:31328295.

22. Gabardo MC, da Silva WJ, Olandoski M, Moysés ST, Moysés SJ. Inequalities in public water supply fluoridation in Brazil: an ecological study. BMC Oral Health. 2008;8(1):9. http://dx.doi.org/10.1186/14726831-8-9. PMid:18402688. 